\title{
Population Fluctuation and Determination of The Economic Injury Level and The Economic Threshold for The Sugarbeet Fly, Pegomia hyo-scyami Curtis, in Nobaria Region, El-Behaira Governorate, Egypt.
}

\author{
Zaghloul, O. A. ${ }^{*}$ M. A. Massoud ${ }^{*}$, H. A. A. Mesbah", G. Zarif ${ }^{\star *}$ and R. S. \\ Kandil \\ ${ }^{*}$ Faculty of Agric. (Saba Basha), Alex. Univ., Egypt. \\ ** Plant Protection Research Institute, Agric. Res. Center, Egypt.
}

\begin{abstract}
ABESTRACT: Experiments were conducted in a private farm cultivated with sugarbeet crop (Top cv.) for the two successive seasons of 2013/2014 and 2014/2015 to determine the economic damage threshold levels of Pegomia hyo-scyami Curtis (Diptera: Anthomyidae) under field conditions in Nobaria region, El-Behaira Governorate, Egypt. The results showed that the relationship between the yield of sugarbeet and the infestation of sugarbeet fly, Pegomia hyoscyami Curtis (Pegomyia mixta Vill.) was negative, which is means that an increase in larvae numbers caused a decrease in roots yield and vice-versa.

In both seasons, Pegomyia hyo-scyami Curtis larvae registered two seasonal peaks of abundance that occurred in February and March.

The determined economic threshold level for Pegomia hyo-scyami Curtis was 19 larvae / plant and the economic injury level was 22 larvae / plant in the first season. But the values were 21 larvae / plant and 22 larvae / plant, in respect, in the second season.

Key words: Sugarbeet (Beta vulgaris L.), sugarbeet fly, Pegomia hyo-scyami Curtis, Pegomyia mixta Vill., Economic threshold $\left(E T_{s}\right)$, the economic injury level $\left(E I_{s}\right)$ and roots yield.
\end{abstract}

\section{INTRODUCTION}

Sugarbeet (Beta vulgaris L.) is considered to be the second crop for sugar production in Egypt after the sugarcane crop (Saccharum officinarum L.) since 1982. The area under cultivation has been estimated by 16,000 feddans that participated in $2.5 \%$ of the total production of sugar. Whereas, in 2013 the cultivated area increased upto 423,000 feddans with $53.10 \%$ sugar. Therefore, Sugarbeet crop became the first source of sugar production in Egypt (El-shafei, 2014)

The gap between consumption and production of sugar was 5000 tons (Afifi, 2001). Thus, increasing the area and yield of sugarbeet were important goals of the ministry of agriculture. The importance of this crop is not only to produce sugar, but also to use its diets in feeding animals due to the high nutritive value of sugarbeet leaves. In addition, sugarbeet thrives well in poor, saline, alkaline and calcareous soils, especially in the newly reclaimed soils.

However, the average yield of sugarbeet was 20.3 tons / feddan that could be increased upto 40 tons / Fed. It is well known that the high yield of any crop is the final goal. Pests' infestation is the main limiting factor, which affect the yield quantitatively as well as qualitatively.

Sugarbeet plants attract more than 150 insect species and mites. The sugarbeet fly, Pegomia hyo-scyami Curtis (Pegomyia mixta Vill.) is one of the most 
serious insect pests of sugarbeet plants (Zarif and Hegazi, 1990 and Cooke and Scott, 1993), so sugar beet growers frequently apply chemical compounds with little knowledge of pest numbers and economic levels. Development of a pest management strategy requires establishment of an economic injury levels (EIL $)$ and an economic threshold $\left(E_{\mathrm{s}}\right)$ which relate yield losses and insect control expenses to pest infestation level (Luckmann and Metcalf, 1975). For the important of economic levels in insect pests' controls, several researchers investigated economic levels of some insect pests attacking sugarbeet fields (Cooke and Scott, 1993; Bassyouny, 1998 and Mesbah, 2000).

The present investigation aimed to study the population fluctuation of the sugarbeet fly, Pegomia hyo-scyami Curtis (Pegomyia mixta Vill.), assessment of quantitative, as well as, qualitative yield losses and determination of the economic injury level $\left(E I L_{s}\right)$ and the economic thresholds $\left(E T_{s}\right)$ for the considered insect pest during 2013/2014 and 2014/2015 seasons in Nobaria region, El-Behaira Governorate.

Such objectives could be considered as prerequisite steps for initiating the so-called integrated pest management "IPM".

\section{MATERIALS AND METHOD}

The study site

An area about $157.5 \mathrm{~m}^{2}$ included in a private farm in Nobaria region, $84 \mathrm{Km}$ South West of Alexandria city, cultivated with sugarbeet (Top cv.) for the two successive seasons of 2013/2014 and 2014/2015.

\section{Experimental design}

The experiments were carried out to study the population fluctuation and determine both the economic injury levels (EILs) and the economic thresholds $\left(E T_{s}\right)$ for the sugarbet fly, Pegomia hyo-scyami Curtis. The experimental area was subdivided into 15 plots (replicates) of $10.5 \mathrm{~m}^{2}(3 \times 3.5 \mathrm{~m})$, each representing the four cardinal directions. Weekly samples (reading) of 3 plants / replicate were chosen, randomly, to record the number of larvae of the assigned insect pest. All plants received the same agricultural practices throughout the course of this study, with no insecticidal sprays.

\section{Determination of the economic injury levels and the economic thresholds (EIL $\mathrm{L}_{\mathrm{s}}$ and $\mathrm{ET}_{\mathrm{s}}$ ) of Pegomia hyo-scyami Curtis infesting sugarbeet plants}

Both the EILs and ETs were determined according to the techniques of (Sherief et al., 2009 and Amal, 2013) as follows:

Values of yield per plant were characterized with the straight line equation: $\hat{Y}=a+b x($ Golden, 1960): where, $\hat{Y}=$ expected yield, $a=$ intercept, $b=$ slope of the regression line and $\mathrm{x}=$ the number of (Pegomia hyo-scyami Curtis and designing the regression line by $\mathrm{Chi}-\mathrm{X}^{2}$ to calculate both the economic threshold $(E T)$ and the economic injury levels (EIL). The populations of the insect pest were 
done and the simple correlation coefficient $(r)$ was calculated between any two characters ( $x$ and $y)$, each with number of observations as follows:

$\hat{\mathbf{Y}}=\mathrm{a}+\mathrm{bx}$

$$
a=\bar{y}-b x^{`}
$$

$$
\begin{gathered}
\mathbf{b}=\frac{\sum x y-\frac{\left(\sum x\right)\left(\sum y\right)}{n}}{\left(\sum x^{2}-\frac{\left(\sum x\right)^{2}}{n}\right.} \\
\mathbf{P i}=\frac{x}{R}
\end{gathered}
$$$$
x^{2}=\frac{\sum x \times p i-\left(\sum x \times p^{\prime}\right)}{P^{\prime} \times q^{\prime}}
$$

$\mathbf{x}=$ mean number of larvae.

$\mathbf{R}=$ size of sample (mean number of leaves during the growing season).

$$
\mathbf{P}^{\prime}=\frac{\sum p}{n} \quad \mathbf{q}^{\prime}=1-\mathrm{p}^{\prime}
$$

$\mathrm{n}=$ number of plants in replicates.

$$
r=\frac{\left(\sum x y-\frac{\left(\sum x\right)\left(\sum y\right)}{n}\right)}{\sqrt{\left(\sum x^{2}-\frac{\left(\sum x\right)^{2}}{n}\right)\left(\sum y^{2}-\frac{\left(\sum y\right)^{2}}{n}\right)}}
$$

\section{RESULTS AND DISCUSSION}

\section{Population fluctuation of Pegomia hyo-scyami larvae in sugarbeet fields during the first season of $2013 / 2014$}

Results revealed that sugarbeet plants were attacked by the sugarbeet fly under field conditions during the first season of 2013/2014. The listed results in Table (1) elucidated the seasonal fluctuations of Pegomia hyo-scyami Curtis on sugarbeet plants during the first season of 2013/2014. Results showed that Pegomia hyo-scyami Curtis larvae have been occurred throughout the period from late December till mid-April on sugarbeet plants during the first season, but in the second season larvae were noticed from late December till the $2^{\text {nd }}$ week of April (Table 3), this extended period might be due to the environmental factors. The seasonal fluctuations of the insect population density, Pegomia hyo-scyami Curtis, referred to two peaks during the both seasons.

In the first season of 2013/2014, the first appearance of 6 larvae / 15 sample on the $4^{\text {th }}$ week of December. Two peaks were achieved on the $2^{\text {nd }}$ week of February and mid-March in the first season with means of 54 and 46 larvae / 15 replicates, respectively, followed by a considerable decline in the mean larval populations (Table 1). 
Table (1). Weekly mean number of Pegomia hyo-scyami Curtis larvae / sample infesting sugarbeet (Top Cv.) under the field conditions at Nobaria region during the first season of 2013/2014.

\begin{tabular}{|c|c|c|c|c|c|c|c|c|c|c|c|c|c|c|c|c|c|}
\hline \multirow{2}{*}{\multicolumn{2}{|c|}{ Weekly inspection }} & \multicolumn{15}{|c|}{ Mean number of larvae / 3 plants } & \multirow{2}{*}{ Total } \\
\hline & & N1 & N2 & N3 & $\mathbf{N 4}$ & N5 & N6 & N7 & N8 & N9 & N10 & N11 & N12 & N13 & N14 & N15 & \\
\hline \multirow{4}{*}{$\begin{array}{c}\text { November } \\
2013\end{array}$} & $1^{\text {st }}$ & 0 & 0 & 0 & 0 & 0 & 0 & 0 & 0 & 0 & 0 & 0 & 0 & 0 & 0 & 0 & 0 \\
\hline & $2^{\text {nd }}$ & 0 & 0 & 0 & 0 & 0 & 0 & 0 & 0 & 0 & 0 & 0 & 0 & 0 & 0 & 0 & 0 \\
\hline & $3^{r a}$ & 0 & 0 & 0 & 0 & 0 & 0 & 0 & 0 & 0 & 0 & 0 & 0 & 0 & 0 & 0 & 0 \\
\hline & $4^{\text {tn }}$ & 0 & 0 & 0 & 0 & 0 & 0 & 0 & 0 & 0 & 0 & 0 & 0 & 0 & 0 & 0 & 0 \\
\hline \multirow{4}{*}{$\begin{array}{c}\text { December } \\
2013\end{array}$} & $1^{\text {st }}$ & 0 & 0 & 0 & 0 & 0 & 0 & 0 & 0 & 0 & 0 & 0 & 0 & 0 & 0 & 0 & 0 \\
\hline & $2^{\text {nd }}$ & 0 & 0 & 0 & 0 & 0 & 0 & 0 & 0 & 0 & 0 & 0 & 0 & 0 & 0 & 0 & 0 \\
\hline & $3^{r a}$ & 0 & 0 & 0 & 0 & 0 & 0 & 0 & 0 & 0 & 0 & 0 & 0 & 0 & 0 & 0 & 0 \\
\hline & $4^{\mathrm{tn}}$ & 1 & 1 & 0 & 1 & 1 & 0 & 0 & 0 & 1 & 1 & 0 & 0 & 0 & 0 & 0 & 6 \\
\hline \multirow{4}{*}{$\begin{array}{c}\text { January } \\
2014\end{array}$} & $1^{\mathrm{St}}$ & 1 & 2 & 3 & 1 & 2 & 0 & 0 & 1 & 1 & 2 & 1 & 1 & 0 & 1 & 2 & 18 \\
\hline & $2^{\text {na }}$ & 1 & 2 & 3 & 2 & 2 & 2 & 1 & 1 & 1 & 2 & 1 & 1 & 0 & 1 & 2 & 22 \\
\hline & $3^{\text {ra }}$ & 1 & 3 & 4 & 2 & 2 & 2 & 1 & 2 & 1 & 2 & 1 & 1 & 3 & 1 & 2 & 28 \\
\hline & $4^{\text {th }}$ & 2 & 3 & 4 & 2 & 2 & 3 & 1 & 2 & 1 & 3 & 4 & 1 & 3 & 3 & 2 & 36 \\
\hline \multirow{4}{*}{$\begin{array}{l}\text { February } \\
2014\end{array}$} & $1^{\text {st }}$ & 3 & 3 & 5 & 2 & 3 & 3 & 1 & 2 & 1 & 3 & 4 & 1 & 4 & 3 & 2 & 40 \\
\hline & $2^{\text {nd }}$ & 6 & 3 & 5 & 2 & 5 & 3 & 3 & 2 & 3 & 5 & 4 & 3 & 5 & 3 & 2 & 54 \\
\hline & $3^{r a}$ & 4 & 4 & 4 & 2 & 4 & 3 & 2 & 3 & 3 & 3 & 4 & 3 & 4 & 3 & 2 & 48 \\
\hline & $4^{\text {th }}$ & 2 & 3 & 3 & 2 & 2 & 3 & 1 & 2 & 1 & 2 & 2 & 1 & 3 & 3 & 2 & 32 \\
\hline \multirow{4}{*}{$\begin{array}{c}\text { March } \\
2014\end{array}$} & $1^{\text {st }}$ & 1 & 3 & 4 & 2 & 2 & 2 & 1 & 2 & 1 & 2 & 1 & 1 & 2 & 1 & 1 & 26 \\
\hline & $2^{\text {na }}$ & 3 & 3 & 5 & 2 & 3 & 3 & 2 & 2 & 3 & 3 & 3 & 4 & 4 & 3 & 3 & 46 \\
\hline & $3^{\text {ra }}$ & 2 & 2 & 3 & 2 & 2 & 1 & 1 & 2 & 1 & 2 & 2 & 1 & 3 & 3 & 2 & 29 \\
\hline & $4^{\mathrm{tn}}$ & 1 & 2 & 3 & 2 & 2 & 2 & 1 & 1 & 0 & 2 & 1 & 1 & 0 & 1 & 2 & 21 \\
\hline \multirow{4}{*}{$\begin{array}{l}\text { April } \\
2014\end{array}$} & $1^{\text {st }}$ & 1 & 1 & 1 & 1 & 1 & 0 & 0 & 0 & 1 & 1 & 0 & 0 & 0 & 0 & 0 & 7 \\
\hline & $2^{\text {nd }}$ & 0 & 0 & 1 & 0 & 1 & 0 & 0 & 0 & 0 & 0 & 0 & 0 & 0 & 0 & 0 & 2 \\
\hline & $3^{\text {ra }}$ & 0 & 0 & 0 & 0 & 0 & 0 & 0 & 0 & 0 & 0 & 0 & 0 & 0 & 0 & 0 & 0 \\
\hline & $4^{\text {th }}$ & 0 & 0 & 0 & 0 & 0 & 0 & 0 & 0 & 0 & 0 & 0 & 0 & 0 & 0 & 0 & 0 \\
\hline May 2014 & $1^{\mathrm{st}}$ & 0 & 0 & 0 & 0 & 0 & 0 & 0 & 0 & 0 & 0 & 0 & 0 & 0 & 0 & 0 & 0 \\
\hline \multicolumn{2}{|l|}{ Total } & 29 & 35 & 48 & 25 & 34 & 27 & 15 & 22 & 19 & 33 & 28 & 19 & 31 & 26 & 24 & 415 \\
\hline \multicolumn{2}{|c|}{ Yield (Kg) } & 1.2 & 0.7 & 0.6 & 1.8 & 0.8 & $\begin{array}{ll}1.7 \\
\end{array}$ & 2.6 & 1.9 & 2.4 & 0.8 & 1.4 & 2.5 & 1.0 & 1.7 & 1.8 & \\
\hline
\end{tabular}


J. Adv. Agric. Res. (Fac. Agric. Saba Basha)

Determination of the economic injury level and the economic threshold for Pegomia hyo-scyami infesting sugarbeet plants during the first season of 2013/2014

As seen in Table (2) and illustrated in Fig (1), the obtained data evaluated that during the season of 2013/2014, upto 19 larvae / plant were observed. The value (5.18) of $X^{2}$ expressed insignificant yield reduction that ranged from 2.4 to $2.5 \mathrm{~kg}$ / plant as a result of no change in the infestation rate of 19 larvae / plant, while the $x^{2}$ value $\left(21.12^{*}\right)$ became significant as the numbers reached 22 larvae / plant. In other words, when number of individuals / plant reached $22\left(E I L_{s}\right)$ significant drop in yield occurred and the value before 19 could be considered as an economic threshold (ET). The relationship between the yield and the infestation was negative, with a coefficient $r=-0.9214$ and coefficient regression $b=-0.0758$.

Table (2). Economic injury level (EIL $\mathrm{L}_{\mathrm{s}}$ ) of Pegomia hyo-scyami Curtis larvae / sample infesting sugarbeet (Top CV.) under the field conditions at Nobaria region during the first season of 2013/2014.

\begin{tabular}{|c|c|c|c|c|c|c|c|c|}
\hline \multirow{3}{*}{$\begin{array}{l}\text { Number } \\
\text { of plant }\end{array}$} & \multirow{2}{*}{$\begin{array}{l}\text { Number } \\
\text { of larvae / } \\
\text { replicate }\end{array}$} & \multirow{2}{*}{$\begin{array}{l}\text { Yield } \\
\text { (Kg) }\end{array}$} & Modified & \multirow{2}{*}{$\begin{array}{c}\text { Size } \\
\text { sample }\end{array}$} & \multirow[t]{2}{*}{$\mathbf{P}$} & \multirow{2}{*}{$X \times P$} & \multirow{2}{*}{$\begin{array}{l}X_{\Sigma \times\left(p^{\prime}\right) / p^{\prime} \times q^{\prime}}=\end{array}$} & $\begin{array}{c}\mathrm{X}^{2} \\
\text { Table }\end{array}$ \\
\hline & & & $\Lambda$ & & & & & \multirow{2}{*}{$5 \%$} \\
\hline & $\mathbf{X}$ & $\mathbf{Y}$ & $\mathbf{Y}$ & $\mathbf{R}$ & $=\mathrm{X} / \mathrm{R}$ & & & \\
\hline 1 & 15 & 2.6 & 2.49 & 20 & 0.750 & 11.250 & 0.00 & 3.84 \\
\hline 2 & 19 & 2.5 & 2.18 & 20 & 0.950 & 18.050 & 3.14 & 5.99 \\
\hline 3 & 19 & 2.4 & 2.18 & 20 & 0.950 & 18.050 & 5.18 & 7.82 \\
\hline 4 & 22 & 1.9 & 1.96 & 20 & 1.100 & 24.200 & 21.12 & 9.49 \\
\hline 5 & 24 & 1.8 & 1.80 & 20 & 1.200 & 28.800 & 236.36 & 11.07 \\
\hline 6 & 25 & 1.8 & 1.73 & 20 & 1.250 & 31.250 & -100.65 & 12.59 \\
\hline 7 & 26 & 1.7 & 1.65 & 20 & 1.300 & 33.800 & -61.23 & 14.07 \\
\hline 8 & 27 & 1.7 & 1.58 & 20 & 1.350 & 36.450 & -51.42 & 15.51 \\
\hline 9 & 28 & 1.4 & 1.50 & 20 & 1.400 & 39.200 & -47.91 & 16.92 \\
\hline 10 & 29 & 1.2 & 1.43 & 20 & 1.450 & 42.050 & -46.86 & 18.31 \\
\hline 11 & 31 & 1.0 & 1.27 & 20 & 1.550 & 48.050 & -48.48 & 19.68 \\
\hline 12 & 33 & 0.8 & 1.12 & 20 & 1.650 & 54.450 & -51.93 & 21.03 \\
\hline 13 & 34 & 0.8 & 1.05 & 20 & 1.700 & 57.800 & -55.04 & 22.36 \\
\hline 14 & 35 & 0.7 & 0.97 & 20 & 1.750 & 61.250 & -57.99 & 23.69 \\
\hline 15 & 48 & 0.6 & -0.02 & 20 & 2.400 & 115.200 & -86.31 & 25.00 \\
\hline Sum & 415 & 22.90 & & & & & & \\
\hline
\end{tabular}
$\mathbf{r}=-0.9214$
$\mathbf{a}=3.6263$
$\mathbf{b}=-0.0758$ 


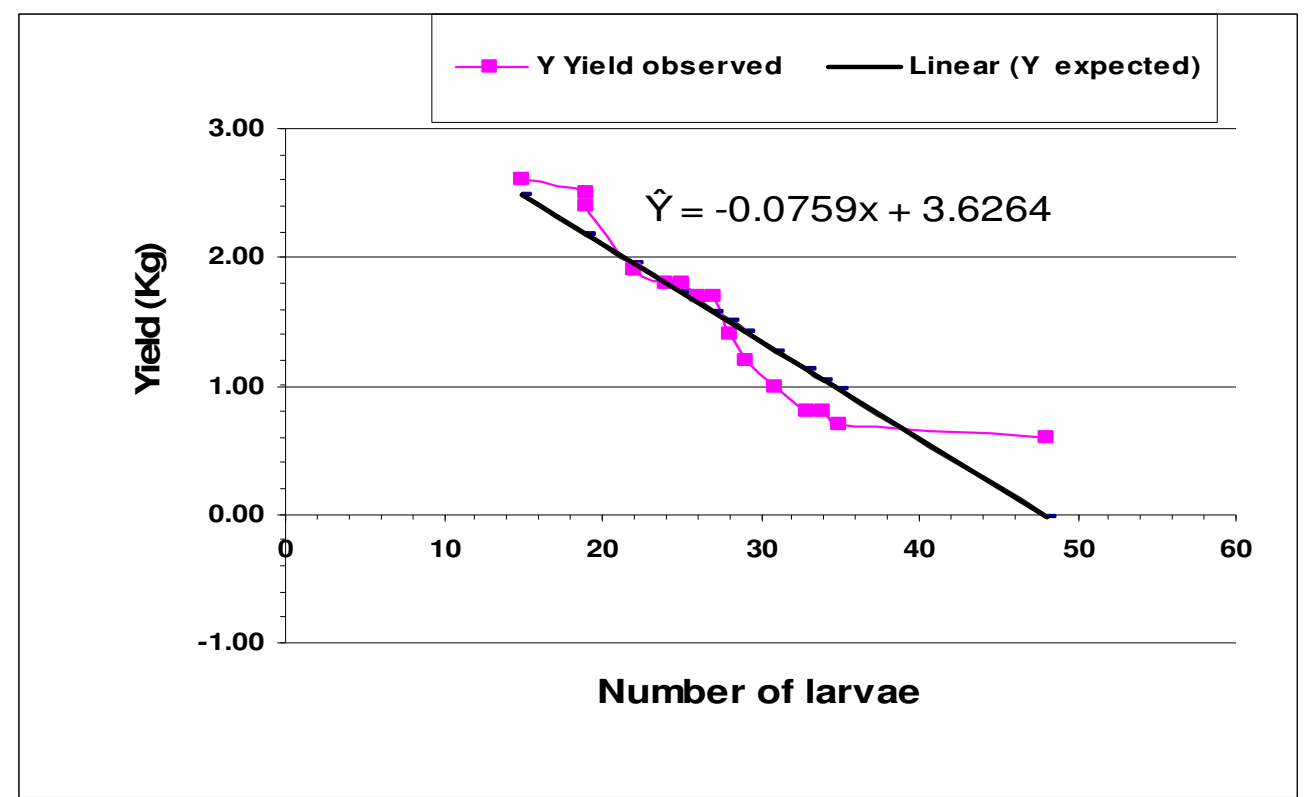

Fig (1). Regressing yield (Kg) against number of Pegomia hyo-scyami Curtis larvae / sample infesting sugarbeet (Top cv.) under the field conditions at Nobaria region during the first season of 2013/2014.

Population fluctuation of Pegomia hyo-scyami larvae in sugarbeet fields during the second season of $2014 / 2015$

In the second season of 2014/2015, the first appearance of 9 larvae / plant corresponded to the $4^{\text {th }}$ week of December. Two peaks were observed at late February and mid-March, which represented by 42 and 41 larvae / 15 samples, respectively, with considerable decline in larval populations afterwards (Table 3). 
Table (3). Weekly mean number of Pegomia hyo-scyami Curtis larvae / sample infesting sugarbeet (Top cv.) under the field conditions at Nobaria region during the second season of 2014/2015.

\begin{tabular}{|c|c|c|c|c|c|c|c|c|c|c|c|c|c|c|c|c|c|}
\hline \multirow{2}{*}{\multicolumn{2}{|c|}{$\begin{array}{c}\text { Weekly } \\
\text { inspection }\end{array}$}} & \multicolumn{15}{|c|}{ Mean number of larvae / 3 plants } & \multirow{2}{*}{ Total } \\
\hline & & N1 & N2 & N3 & N4 & N5 & N6 & N7 & N8 & N9 & N10 & N11 & N12 & N13 & N14 & N15 & \\
\hline \multirow{3}{*}{$\begin{array}{l}\text { November } \\
2014\end{array}$} & $1^{\text {st }}$ & 0 & 0 & 0 & 0 & 0 & 0 & 0 & 0 & 0 & 0 & 0 & 0 & 0 & 0 & 0 & 0 \\
\hline & $2^{\text {na }}$ & 0 & 0 & 0 & 0 & 0 & 0 & 0 & 0 & 0 & 0 & 0 & 0 & 0 & 0 & 0 & 0 \\
\hline & $4^{\text {th }}$ & 0 & 0 & 0 & 0 & 0 & 0 & 0 & 0 & 0 & 0 & 0 & 0 & 0 & 0 & 0 & 0 \\
\hline \multirow{2}{*}{$\begin{array}{c}\text { December } \\
2014\end{array}$} & $1^{\mathrm{st}}$ & 0 & 0 & 0 & 0 & 0 & 0 & 0 & 0 & 0 & 0 & 0 & 0 & 0 & 0 & 0 & 0 \\
\hline & $2^{\text {na }}$ & 0 & 0 & 0 & 0 & 0 & 0 & 0 & 0 & 0 & 0 & 0 & 0 & 0 & 0 & 0 & 0 \\
\hline \multirow{4}{*}{$\begin{array}{c}\text { January } \\
2015\end{array}$} & $1^{\text {st }}$ & 0 & 2 & 1 & 1 & 2 & 0 & 3 & 1 & 2 & 1 & 0 & 1 & 1 & 1 & 2 & 18 \\
\hline & $2^{\text {nd }}$ & 1 & 1 & 1 & 2 & 2 & 2 & 3 & 1 & 3 & 2 & 1 & 1 & 1 & 1 & 2 & 24 \\
\hline & $3^{r a}$ & 1 & 2 & 2 & 3 & 2 & 1 & 3 & 2 & 3 & 2 & 1 & 3 & 2 & 1 & 2 & 30 \\
\hline & $4^{\text {th }}$ & 2 & 3 & 3 & 1 & 2 & 3 & 2 & 2 & 2 & 1 & 2 & 1 & 2 & 2 & 2 & 30 \\
\hline \multirow{2}{*}{$\begin{array}{l}\text { February } \\
\quad 2015\end{array}$} & $1^{\mathrm{st}}$ & 2 & 2 & 3 & 2 & 3 & 3 & 3 & 2 & 3 & 2 & 2 & 2 & 3 & 3 & 2 & 37 \\
\hline & $2^{\text {nd }}$ & 2 & 3 & 3 & 2 & 2 & 3 & 2 & 2 & 2 & 1 & 2 & 1 & 3 & 2 & 2 & 32 \\
\hline \multirow{2}{*}{$\begin{array}{l}\text { March } \\
2015\end{array}$} & $3^{r a}$ & 1 & 3 & 3 & 2 & 2 & 3 & 2 & 2 & 2 & 1 & 2 & 2 & 1 & 2 & 2 & 30 \\
\hline & $4^{\text {th }}$ & 2 & 1 & 2 & 1 & 2 & 0 & 0 & 1 & 1 & 2 & 1 & 1 & 1 & 2 & 1 & 18 \\
\hline \multirow{4}{*}{$\begin{array}{l}\text { April } \\
2015\end{array}$} & $1^{\mathrm{st}}$ & 1 & 1 & 1 & 0 & 1 & 1 & 0 & 0 & 1 & 2 & 1 & 0 & 1 & 0 & 1 & 11 \\
\hline & $2^{\text {na }}$ & 1 & 0 & 1 & 0 & 1 & 0 & 1 & 0 & 2 & 1 & 0 & 0 & 1 & 0 & 0 & 8 \\
\hline & $3^{r a}$ & 0 & 0 & 0 & 0 & 0 & 0 & 0 & 0 & 0 & 0 & 0 & 0 & 0 & 0 & 0 & 0 \\
\hline & $4^{\text {tn }}$ & 0 & 0 & 0 & 0 & 0 & 0 & 0 & 0 & 0 & 0 & 0 & 0 & 0 & 0 & 0 & 0 \\
\hline May 2015 & $1^{\mathrm{st}}$ & 0 & 0 & 0 & 0 & 0 & 0 & 0 & 0 & 0 & 0 & 0 & 0 & 0 & 0 & 0 & 0 \\
\hline \multicolumn{2}{|c|}{ Total } & 20 & 27 & 35 & 21 & 31 & 29 & 30 & 19 & 34 & 24 & 19 & 18 & 25 & 22 & 26 & 380 \\
\hline \multicolumn{2}{|c|}{ Yield (Kg) } & 2.1 & 1.4 & 0.6 & 2.0 & 0.8 & 1.0 & 1.0 & 2.4 & 0.7 & 1.7 & 2.5 & 2.6 & 1.7 & 1.9 & 1.5 & \\
\hline
\end{tabular}


Determination of the economic injury level and the economic threshold for Pegomia hyo-scyami infesting sugarbeet plants during the second season of 2014/2015

Data listed in Table (4) and Fig (2) cleared that during the season of $2014 / 2015$ insignificant reduction occurred in yield from 2.1 to $2.0 \mathrm{~kg} /$ plant as a result of increasing the number of larvae / plant from 20 to 21 while, when the number of larvae per plant raised upto 22 , the $X^{2}$ value $\left(65.55^{\star}\right)$ witnessed significance. In other words, when number of larvae / plant reached 22 (EIL) significant drop in yield occurred and the value before 21 could be taken as an economic threshold (ET). The relationship between the yield and the infestation was also negative, similar to the first season, with a coefficient $r=-0.9860$ and coefficient regression $b=-0.1178$.

Table (4). Economic injury level (EILs) of Pegomia hyo-scyami Curtis larvae / sample infesting sugarbeet (Top Cv.) under the field conditions at Nobaria region during the second season of 2014/2015.

\begin{tabular}{|c|c|c|c|c|c|c|c|c|}
\hline \multirow[t]{2}{*}{$\begin{array}{l}\text { Number } \\
\text { of plant }\end{array}$} & \multirow{2}{*}{$\begin{array}{c}\begin{array}{c}\text { Number } \\
\text { of larvae / } \\
\text { replicate }\end{array} \\
\mathbf{x} \\
\end{array}$} & $\begin{array}{l}\text { Yield } \\
\text { (Kg) }\end{array}$ & \multirow{2}{*}{$\begin{array}{c}\text { Modified } \\
\hat{\Lambda} \\
\mathbf{Y}\end{array}$} & \multirow{2}{*}{$\begin{array}{c}\begin{array}{c}\text { Size } \\
\text { sample }\end{array} \\
\mathbf{R}\end{array}$} & \multirow{2}{*}{$\begin{array}{c}\mathbf{P} \\
=\mathrm{X} / \mathrm{R}\end{array}$} & \multirow[t]{2}{*}{$X \times P$} & \multirow[t]{2}{*}{$\begin{array}{l}X^{2}=(\Sigma x \times p i- \\
\left.\Sigma \times \times p^{\prime}\right) / p^{\prime} \times q^{\prime}\end{array}$} & \multirow[t]{2}{*}{$\begin{array}{c}X^{2} \\
\text { Table } \\
5 \% \\
\end{array}$} \\
\hline & & $\mathbf{Y}$ & & & & & & \\
\hline 1 & 18 & 2.6 & 2.46 & 20 & 0.900 & 16.200 & 0.00 & 3.84 \\
\hline 2 & 19 & 2.5 & 2.34 & 20 & 0.950 & 18.050 & 0.36 & 5.99 \\
\hline 3 & 19 & 2.4 & 2.34 & 20 & 0.950 & 18.050 & 0.54 & 7.82 \\
\hline 4 & 20 & 2.1 & 2.22 & 20 & 1.000 & 20.000 & 2.11 & 9.49 \\
\hline 5 & 21 & 2.0 & 2.10 & 20 & 1.050 & 22.050 & 8.93 & 11.07 \\
\hline 6 & 22 & 1.9 & 1.99 & 20 & 1.100 & 24.200 & 65.55 & 12.59 \\
\hline 7 & 24 & 1.7 & 1.75 & 20 & 1.200 & 28.800 & -58.74 & 14.07 \\
\hline 8 & 25 & 1.7 & 1.63 & 20 & 1.250 & 31.250 & -41.90 & 15.51 \\
\hline 9 & 26 & 1.5 & 1.51 & 20 & 1.300 & 33.800 & -39.50 & 16.92 \\
\hline 10 & 27 & 1.4 & 1.40 & 20 & 1.350 & 36.450 & -40.03 & 18.31 \\
\hline 11 & 29 & 1.0 & 1.16 & 20 & 1.450 & 42.050 & -43.94 & 19.68 \\
\hline 12 & 30 & 1.0 & 1.04 & 20 & 1.500 & 45.000 & -47.49 & 21.03 \\
\hline 13 & 31 & 0.8 & 0.93 & 20 & 1.550 & 48.050 & -50.91 & 22.36 \\
\hline 14 & 34 & 0.7 & 0.57 & 20 & 1.700 & 57.800 & -58.25 & 23.69 \\
\hline 15 & 35 & 0.6 & 0.45 & 20 & 1.750 & 61.250 & -64.14 & 25.00 \\
\hline Sum & 380 & 23.90 & & & & & & \\
\hline
\end{tabular}

$r=-0.9860$

$\mathbf{a}=4.5787$

$\mathbf{b}=-0.1178$ 


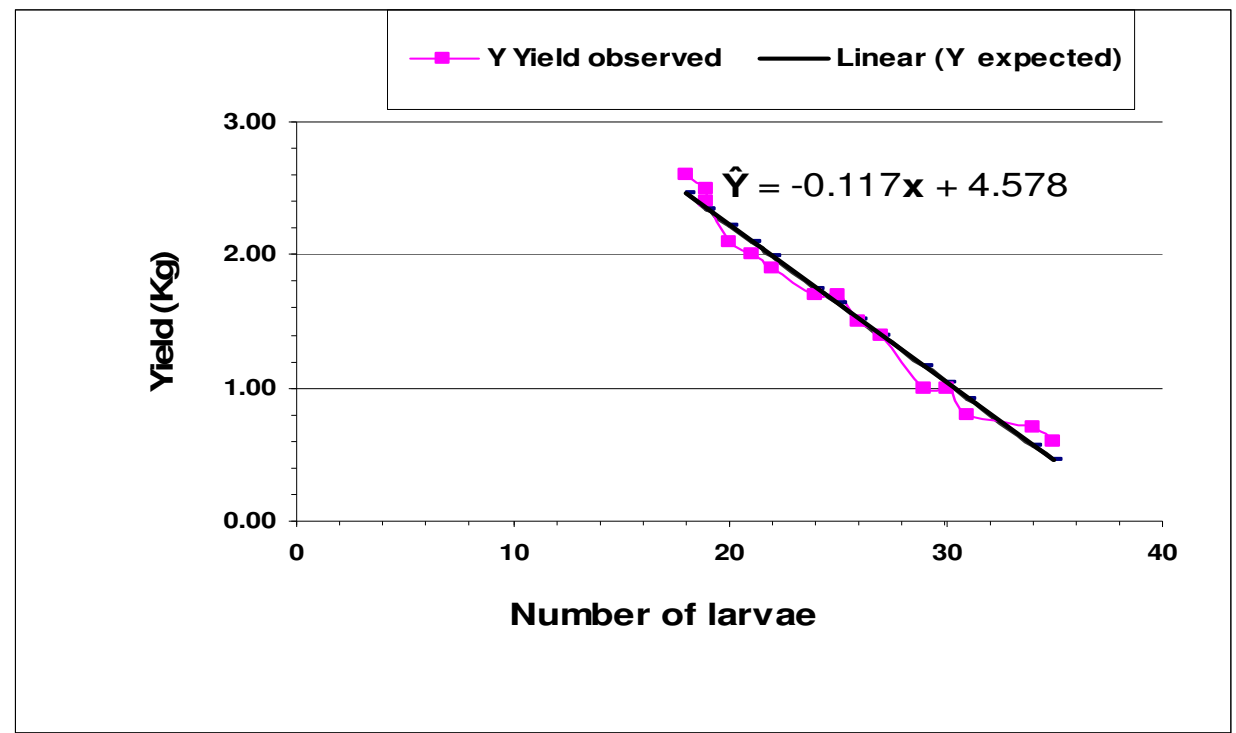

Fig (2). Regressing yield (Kg) against number of Pegomia hyo-scyami Curtis larvae / sample infesting sugarbeet (Top cv.) under the field conditions at Nobaria region during the second season of 2014/2015.

The obtained findings of the present study were in harmony with the findings of others such as Youssef (1994) and Ebieda (1997) who stated that Pegomia mixta was commonly found in sugarbeet more than other crops, causing a considerable reduction in yield. In this respect, Bassyouny (1998) found that the late plantation of sugarbeet in October was severely attacked by Pegomia hyoscyami Curtis.

El-Khouly (2006) showed that the abundance of Pegomia mixta was associated with the reliable occurrence of their natural enemies. He also, referred that three seasonal peaks of Pegomia mixta were recorded and declared that the initial appearance of Pegomia mixta survivors occurred in April 2005 and 2006.

Mohisen (2012) stated that larvae of Pegomia mixta attacked sugarbeet plantations from November until late February, and reached its maximum abundance during spring i.e. from March to May in Kafr El-sheikh governorate. ElDesssouki et al. (2014) mentioned that larvae of Pegomia mixta recorded three peaks of seasonal abundance in both seasons (2011 and 2012) during late December, early February and mid-March in the first season of 2011 and during mid-December, late January and mid-March in the second season of 2012.

Accordingly, all the earlier results on of Pegomia hyo-scyami Curtis populations were in accordance with those obtained in this study, in the sense that the pest abundance occurred in February and March. 
J. Adv. Agric. Res. (Fac. Agric. Saba Basha)

\section{REFERENCES}

Afifi, F. (2001). Developing of cultivation and production of sugar corps in Egypt (1981-2000) present and future vision of sugar industry. Egyptian Society of Sugar Technologists, the $31^{\text {st }}$ Annual Conference, Luxor, Egypt, 27-29 January, pp 7-19.

Amal, Z. N. Al-Habashy (2013). The economic injury level of Cassida vittata (vill.) on sugarbeet plants. Acad. J. Biol. Sci. Egypt, 6(2): 159 - 168.

Email: egyptianacademic@yahoo.com.

Bassyouny, A. M. (1998). Economic injury level of the main defoliator insects on sugarbeet plants. J. Agric. Sci., Mansoura Univ., 23(1): 405-418.

Cooke, D. A. and R. K. Scott (1993). The sugarbeet crop. 11-Pests. Pusblished by Shapman and Hall. ISBN 0412251302 p. 429-83.

Ebieda, A. M. M. (1997). Studies on sugarbeet pests. V. Effect of the tortoise beetle Cassida vittata Vill (Coleoptera : Chrysomelidae ) on sugarbeet with special reference to determination of economic threshold. Advance in Agric. Res., 2(1): 1-11.

El-Dessouki, S. A., S. M. El-Awady, K. A. M. H. El-Khawass, A. H. Mesbah and El-Dessouki, W. A. A. (2014). Population fluctuations of some insect pests infesting sugarbeet and the associated predatory insects at Kafr El-Sheikh Governorate. Annals Agric. Sci., 59(1): 119-123.

El-Khouly, M. I. (2006). Population fluctuations of the beet fly, Pegomyia mixta Vill. and the tortoise beetle, Cassida vittata Vill. in relation to certain associated natural enemies in sugarbeet fields at Kafr El-Sheikh Governorate, Egypt. Egyptian J. Bio. Pest control, 16(1): 25-28.

El-Shafei, A. (2014). Sugarbeet cultivation in the new reclaimed land. Sugar Crop Research Institute, Ministry of Agriculture and Land Reclamations, Giza, Egypt, 24 (In Arabic).

Golden, C. H. (1960). Methods of statically analysis. M.c. Graw Hill, London.

Luckmann, W. H. and R. L. Metcalf (1975). The pest management concept. P. 3$35 \mathrm{RL}$. Metcalf. Eds. Introduction to insect pest management. Wiley Inter Science, New Yourk, London, Toronto. 587 pp.

Mesbah, I. I. (2000). Economic threshold of infestation with the beet fly, Pegomyia mixta Vill. In sugarbeet fields at Kafr El-Sheikh Region. J. Agric. Res. Tanta Univ., 26(3): 508-514.

Mohisen, M. A. A. (2012). Studies on some insects infesting sugar crops. M.Sc. Thesis, Fac. of Agric. Al-Azhar Univ. Cairo, Egypt, $211 \mathrm{pp}$.

Sherief, E. A. H., Saadia A. Abd- El-Basier and S. H. A. Hussein (2009): The Economic Injury Level of Spodoptera littoralis (Bosid.) And toxic effect of certain compounds on sugarbeet at Fayoum Governorate. Egypt. J. of Appl. Sci., 24(8B): 683-693.

Youssef, A. E. (1994). Studies on certain insects attacking sugarbeet. Ph.D. Thesis, Faculty of Agriculture, Tanta Univ. Kafr El-Sheikh, Egypt, 130 pp.

Zarif, G. and E. M. Hegazi (1990). Effect of nitrogen fertilization and sugarbeet cultivars on population of Pegomyia mixta Vill. (Diptera : Anthomyidae). Com. Sci. \& Dev. Res., 29: 1-10. 


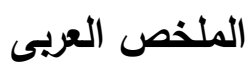

التذبذبات العددية وتحديد مستوى الضرر الإقتصادى والحدالحرج للإصابة بذبابة أوراق Pegomia hyo-scyami Curtis

عثمان أحمد زغلول * و مجدى عبدالظاهر مسعود * و حسن على عبدالحميا مصباح * و جورج ظريف ** * و رجب سبيته قنديل

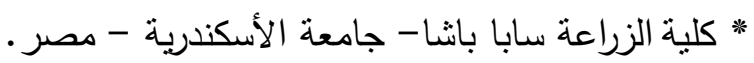
**** معهد بحوث وقاية النباتات - مركز البحوث الزراعية - مصر .

أجريت التجارب في مزرعة خاصة مزروعة بمحصول بنجر السكر صنف توب (Top cv.) لموسمين متتاليين

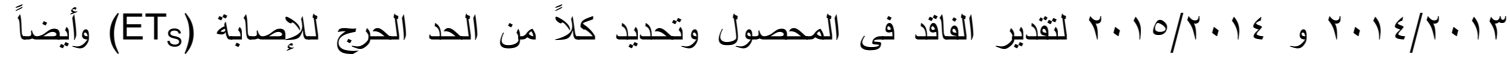
مستويات الضرر الإقتصادية (EILs) الناجمة عن الإصابة بحشرة ذبابة أوراق البنجر بمنطقة النوبارية بمحافظة البحيرة فى مصر • ولقد أوضحت النتائج أن العلاقة بين محصول بنجر السكر والإصابة بذبابة أوراق البنجر كانت معنوية فكلما زاد معدل الإصابة باليرقات قل المحصول بالتالى والعكس صحيح. وفى كلا موسمى الزراعة سجلت أعداد برقات ذبابة أوراق البنجر قمتين Peaks فى أثنهر فبراير ومارس. كذلك وجد أن الحد الإقتصادى الحرج للإصابة بذبابة أوراق البنجر كان 19 يرقة لكل نبات ومستوى الضرر الإقتصادى والذى كان بr بر يرقة لكل نبات فى الموسم الأول ؛ بينما

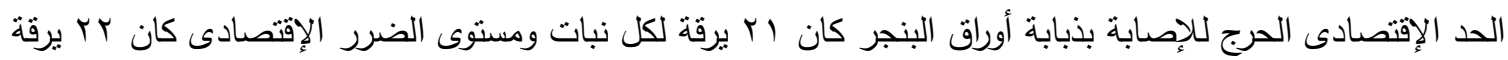

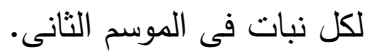


